\title{
Glutathione Cycle Activity and Pyridine Nucleotide Levels in Oxidant-induced Injury of Cells
}

\author{
Ingrid U. Schraufstätter, Daniel B. Hinshaw, Paul A. Hyslop, Roger G. Spragg, and Charles G. Cochrane \\ Department of Immunology, Scripps Clinic and Research Foundation, La Jolla, California 92037; Department of Medicine, \\ University of California, San Diego, California 92103
}

\begin{abstract}
Exposure of target cells to a bolus of $\mathrm{H}_{2} \mathrm{O}_{2}$ induced cell lysis after a latent period of several hours, which was prevented only when the $\mathrm{H}_{2} \mathrm{O}_{2}$ was removed within the first 30 min of injury by addition of catalase. This indicated that early metabolic events take place that are important in the fate of the cell exposed to oxidants.

In this study, we described two early and independent events of $\mathrm{H}_{2} \mathrm{O}_{2}$-induced injury in P388D1 macrophagelike tumor cells: activation of the glutathione cycle and depletion of cellular NAD. Glutathione cycle and hexose monophosphate shunt (HMPS) were activated within seconds after the addition of $\mathrm{H}_{2} \mathrm{O}_{2}$. High HMPS activity maintained glutathione that was largely reduced. However, when HMPS activity was inhibited-by glucose depletion or by incubation at $4^{\circ} \mathrm{C}$-glutathione remained in the oxidized state.

Total pyridine nucleotide levels were diminished when cells were exposed to $\mathrm{H}_{2} \mathrm{O}_{2}$, and the breakdown product, nicotinamide, was recovered in the extracellular medium. Intracellular NAD levels fell by $80 \%$ within 20 min of exposure of cells to $\mathrm{H}_{2} \mathrm{O}_{2}$. The loss of NADP(H) and stimulation of the HMPS could be prevented when the glutathione cycle was inhibited by either blocking glutathione synthesis with buthionine sulfoximine (BSO) or by inhibiting glutathione reductase with (1,3-bis) 2 chlorethyl-1-nitrosourea. The loss of NAD developed independently of glutathione cycle and HMPS activity, as it also occurred in BSO-treated cells.
\end{abstract}

\section{Introduction}

In the process of inflammation, stimulated leukocytes produce proteases and oxidants that are associated with injury of cells and supporting structures of the surrounding tissue. Stimulated neutrophils, as well as enzymatically generated $\mathrm{O}_{2}^{-}$or $\mathrm{H}_{2} \mathrm{O}_{2}$, have been shown to cause cell death in various target cells after a latent period (1-3). Cell lysis has been largely inhibited by catalase and, in some instances, superoxide dismutase, when these enzymes were added early in the time course of oxidant

This paper is publication number 3778 IMM from the Research Institute of Scripps Clinic. Dr. Schraufstätter is a Puritan Bennet Foundation Fellow in Pulmonary Research. Dr. Hinshaw and Dr. Hyslop are recipients of fellowships from the American Lung Association and the American Heart Association.

Address communication and reprint requests to Dr. Schraufstätter, Department of Immunology, Scripps Clinic and Research Foundation. Received for publication 4 March 1985.

J. Clin. Invest.

(C) The American Society for Clinical Investigation, Inc.

0021-9738/85/09/1131/09 \$1.00

Volume 76, September 1985, 1131-1139 formation (1-3). Depletion of cellular reduced glutathione (GSH), an important defense system against oxidants, caused more rapid lysis of target cells (4-6). In this respect, it is of interest that oxidant stress in itself can induce a loss of intracellular glutathione. In isolated perfused liver and in lung, addition of hydroperoxides or stimulated neutrophils led to a decrease of intracellular glutathione and NADPH, and an increase of oxidized glutathione (GSSG) in the perfusate $(7,8)$. The fate of glutathione after exposure to oxidants has also been followed in erythrocytes (9) and hepatocytes (10-12), where oxidation of intracellular glutathione by organic peroxides or oxidant-producing drugs is paralleled by the formation of glutathione-protein mixed disulfides (11).

While the oxidation of GSH has been linked to stimulation of the hexose monophosphate shunt (HMPS, ${ }^{1}$ or pentose phosphate pathway) (13-15), a temporal relationship between exposure of cells to oxidant, changes in the ratio of GSH/GSSG and NADPH/NADP ${ }^{+}$, and activation of the HMPS in a single cell type is unclear. The temporal relationship of these changes to cell death also has not been clearly defined.

In our studies of the effects of oxidants on cells, we therefore undertook an analysis of these temporal relationships. We also examined whether $\mathrm{NADP}^{+}$formation was essential in the stimulation of the HMPS and if activity of the HMPS was required in the maintenance of intracellular levels of GSH during exposure of cells to oxidants. A surprising observation that resulted from the study was a fall in levels of NAD that developed independently of GSH-cycle activity.

\section{Methods}

Cell culture. P388D1 (a macrophagelike tumor cell line that does not produce $\mathrm{O}_{2}^{-}$; obtained from Dr. R. Schreiber, Scripps Clinic and Research Foundation) cells were cultured in RPMI 1640 (Irvine Scientific, Santa Ana, CA), supplemented with $10 \%$ fetal calf serum (Flow Laboratories, Inglewood, CA), $2 \mathrm{mM}$ L-glutamine, and $50 \mu \mathrm{g} / \mathrm{ml}$ gentamycin sulfate (M.A. Bioproducts, Walkersville, MD). Just before the experiment they were removed with a rubber policeman, centrifuged at $400 \mathrm{~g}$ for $5 \mathrm{~min}$, and resuspended in RPMI 1640 or modified Gey's buffer (MGB), which contained $147 \mathrm{mM} \mathrm{NaCl}, 5 \mathrm{mM} \mathrm{KCl}, 1.9 \mathrm{mM} \mathrm{KH}_{2} \mathrm{PO}_{4}, 1.1 \mathrm{mM}$ $\mathrm{Na}_{2} \mathrm{HPO}_{4} \cdot 7 \mathrm{H}_{2} \mathrm{O}, 5.5 \mathrm{mM}$ glucose, $1.5 \mathrm{mM} \mathrm{CaCl}_{2}, 0.3 \mathrm{mM} \mathrm{MgSO}_{4} \cdot 7$ $\mathrm{H}_{2} \mathrm{O}$, and $1 \mathrm{mM} \mathrm{MgCl} \cdot 6 \mathrm{H}_{2} \mathrm{O}, \mathrm{pH}$ 7.4.

For cell lysis studies, $\mathrm{P388D} 1$ cells were labeled with ${ }^{51} \mathrm{Cr}\left({ }^{51} \mathrm{CrO}_{4}\right.$; New England Nuclear, Boston, MA) as described in reference 1. $\left.{ }^{35} \mathrm{~S}\right]$ cysteine $\left(3 \mu \mathrm{Ci} / 10^{7}\right.$ cells) (New England Nuclear) labeling was performed for $2 \mathrm{~h}$ at $37^{\circ} \mathrm{C}$ in $10 \%$ medium 199 in MGB. Cells were washed

1. Abbreviations used in this paper: BCNU, (1,3-bis) 2 chlorethyl-1-nitrosourea; BSO, buthionine sulfoximine; DTT, dithiothreitol; DTNB, 5,5'-dithiobis (2-nitrobenzoic acid); HMPS, hexose monophosphate shunt; HPLC, high performance liquid chromatography; MGB, modified Gey's buffer; TCA, tricarboxylic acid cycle; TLC, thin-layer chromatography; UDP-glucose, uridine diphosphate glucose. 
three times as for ${ }^{51} \mathrm{Cr}$ labeling. In experiments where glucose was omitted from the incubation medium, cells were washed once in glucose-free medium and incubated for $10 \mathrm{~min}$ at $37^{\circ} \mathrm{C}$ before the addition of $\mathrm{H}_{2} \mathrm{O}_{2}$. To obtain human erythrocytes, fresh human blood in acid citrate was centrifuged at $1,000 \mathrm{~g}$ for $10 \mathrm{~min}$, the plasma and buffy coat were removed, and they were washed three times in MGB.

Glutathione depletion. P388D1 cells were depleted of glutathione by incubation with $0.2 \mathrm{mM}$ buthionine sulfoximine (BSO) (Chemalog, Chemical Dynamics Corp., S. Plainfield, NJ) for $18 \mathrm{~h}$ (16). At this time, glutathione levels were between 5 and $10 \%$ of normal. Inhibition of glutathione reductase was achieved by incubation with $75 \mu \mathrm{M}(1,3-b i s) 2$ chloroethyl-1-nitrosourea) (BCNU) (Bristol Laboratories, Syracuse, NY) (4) for $20 \mathrm{~min}$ at $37^{\circ} \mathrm{C}$, which reduced glutathione reductase activity by $>98 \%$.

Enzymatic determination of GSH and GSSG. 10,000 U catalase (from bovine liver; Sigma Chemical Co., St. Louis, MO) were added to each sample $\left(5 \times 10^{6}\right.$ cells) at the end of the incubation period to scavenge any extracellular $\mathrm{H}_{2} \mathrm{O}_{2}$ that could oxidize glutathione nonenzymatically. The cells were centrifuged for $10 \mathrm{~s}$ in a microfuge, the supernatant removed, and the cell pellet deproteinized with $200 \mu \mathrm{l} 2.5 \%$ sulfosalicylic acid in $0.2 \%$ Triton $X-100$. After centrifugation, $100 \mu$ l of supernatant was incubated with $2 \mu \mathrm{l}$ vinylpyridine in $10 \mu \mathrm{l} 1 \mathrm{M}$ Tris base for $50 \mathrm{~min}$ at room temperature (17) for the determinations of GSSG.

Total and oxidized glutathione were determined on 96-well plates in triplicate $10-\mu \mathrm{l}$ samples after addition of $100 \mu \mathrm{l} 0.3 \mathrm{mM} 5,5^{\prime}$ dithiobis (2-nitrobenzoic acid)(DTNB), $100 \mu 10.4 \mathrm{mM}$ NADPH containing 0.12 $\mathrm{U}$ glutathione reductase, and $100 \mu$ phosphate/imidazole buffer, $\mathrm{pH} 7.2$ (18). The difference in optical density at $414 \mathrm{~nm}$ measured on a Titertek reader (Titertek multiskan, Flow Laboratories, McLean, VA) at two time points was used for quantification. $10 \mu \mathrm{l}$ of $0.2 \%$ Triton $\mathrm{X}$ and $2.5 \%$ sulfosalicylic acid were included in the standard curve.

Determination of GSH, GSSG, and protein-mixed disulfides by high performance liquid chromatography (HPLC). Cell pellets from $5 \times 10^{6}$ cells were suspended in $500 \mu \mathrm{l}$ saline and deproteinized with $50 \mu \mathrm{l}$ of $70 \%$ perchloric acid. $5 \mu \mathrm{mol}$ iodoacetic acid was added together with 5 nmol phenanthroline in ethanol and $300 \mu 10.5 \mathrm{M} \mathrm{KHCO}_{3}$ in $2 \mathrm{M} \mathrm{KOH}$. After $15 \mathrm{~min}$ incubation at room temperature in the dark, $350 \mu \mathrm{l}$ of $1.5 \%$ dinitrofluorobenzene was added and incubated for $24 \mathrm{~h}$ in the dark. The derivatized amino acids were separated by HPLC (Series 4 HPLC, Perkin-Elmer Corp., Instrument Div., Norwalk, CT) on a 25-cm Spherisorb 3-amino propyl 5 micron column (Custom LC, Inc., Houston, TX) (19).

In experiments in which recovery of glutathione was measured, cells were prelabeled with $\left[{ }^{35} S\right]$ cysteine, and recovery assessed by scintillation counting of the fractions collected after HPLC separation of GSH and GSSG was between 85 and $90 \%$. About $2 \%$ of the cellular glutathione was measured as GSSG due to oxidation during sample preparation. Glutathione moiety that was bound to protein in the acid-precipitated protein pellet was reduced with dithiothreitol (DTT) and similarly derivatized and separated on HPLC (20).

Determination of NADPH and NADP. The cell pellets prepared as for glutathione determination were alkaline (NADPH) and acid (NADP) extracted, and NADP(H) was measured in 10- $\mu$ l samples by a recycling assay containing GSSG, glucose-6-phosphate, DTNB, glutathione reductase, and glucose-6-phosphate dehydrogenase (21). The validity of the assay was checked using a luminometric assay kit for NADPH (Behring, La Jolla, CA), which measured photon emission in a scintillation counter.

NAD(P) moiety was labeled with ${ }^{14} \mathrm{C}$ by incubating P388D1 cells in complete RPMI 1640 with $12.5 \mu \mathrm{Ci}^{14} \mathrm{C}$-carboxyl nicotinic acid (Amersham Corp., Arlington Heights, IL) for $20 \mathrm{~h}$ at $37^{\circ} \mathrm{C}$. The cells were quickly washed three times. $2 \times 10^{7}$ cells were incubated in complete medium in the presence and absence of $2.5 \mathrm{mM} \mathrm{H}_{2} \mathrm{O}_{2}$. After the addition of $5,000 \mathrm{U}$ catalase and centrifugation at $1,000 \mathrm{~g}$ for $90 \mathrm{~s}$, aliquots of the supernatant and cell pellet were used for scintillation counting. The cell pellet was precipitated with $250 \mu \mathrm{l}$ of $70 \%$ ethanol in $10 \mathrm{mM}$ potassium phosphate buffer, $\mathrm{pH} 7.0$ (22), and incubated at $25^{\circ} \mathrm{C}$ for $30 \mathrm{~min}$. The supernatant after centrifugation was applied on thin-layer chro- matography (TLC) silica plates (HPTLC silica 60, Merck, Darmstadt, Federal Republic of Germany). Pyridine compounds were separated in methanol/acetonitrile/5 mM tetrabutylammonium hydroxide (Sigma Chemical Co.), pH 5.4 (23), visualized in an ultraviolet light of $254 \mathrm{~nm}$, and quantified by scintillation counting.

Alternatively radioactive cell pellet samples from $2.5 \times 10^{7}$ cells were alkaline and acid extracted as for NADP(H) determination, neutralized, and separated on an anion exchange HPLC column (Ultrasil AX anion exchange column, Altex Scientific, Inc., Berkeley, CA) (24). Nucleotide (24) and nucleoside separation (25) were followed at $256 \mathrm{~nm}$. The supernatant was lyophilized, acid extracted, and nucleosides were separated on a C18 reverse-phase HPLC column (DuPont Instruments, Wilmington, DE) (25).

HMPS activity. HMPS activity was measured by incubating $4 \times 10^{6}$ P388D1 cells in $2 \mathrm{ml}$ MGB that contained $5.5 \mathrm{mM}$ glucose and either $0.5 \mu \mathrm{Ci}{ }^{14} \mathrm{C}_{1}$-glucose or $1.5 \mu \mathrm{Ci}^{14} \mathrm{C}_{6}$-glucose (New England Nuclear; 6.4 $\mathrm{mCi} / \mathrm{mmol}$ ) in air-tight $75-\mathrm{ml}$ flasks. To stop the reaction, $200 \mu \mathrm{l}$ of $50 \%$ trichloroacetic acid was injected at various time points, and the flasks were incubated for $1 \mathrm{~h}$. Any $\mathrm{CO}_{2}$ formed was trapped on a cotton swab soaked in $2 \mathrm{M} \mathrm{NaOH}$ which was counted in a scintillation counter after dark adaptation. ${ }^{14} \mathrm{CO}_{2}$ formed by tricarboxylic acid cycle (TCA) activity $\left({ }^{14} \mathrm{C}_{6}\right)$ was subtracted from ${ }^{14} \mathrm{CO}_{2}$ formed from ${ }^{14} \mathrm{C}_{1}$-glucose to give an estimate of HMPS activity.

Determination of $\mathrm{H}_{2} \mathrm{O}_{2} \cdot \mathrm{H}_{2} \mathrm{O}_{2}$ in the extracellular medium (MGB) was determined fluorometrically on $15-\mu$ l aliquots of supernatant, using $250 \mu \mathrm{g}$ parahydroxyphenyl acetic acid and $80 \mu \mathrm{g}$ horseradish peroxidase (26), with excitation and emission wavelengths of 300 and $420 \mathrm{~nm}$.

\section{Results}

Cell lysis induced by exposure to oxidant. Incubation of ${ }^{51} \mathrm{Cr}$ preloaded P388D1 cells $\left(2 \times 10^{6} / \mathrm{ml}\right)$ with a bolus of $\mathrm{H}_{2} \mathrm{O}_{2}$ in a concentration range between 0.5 and $5 \mathrm{mM}$ in RPMI 1640 resulted in gradual ${ }^{51} \mathrm{Cr}$ release over hours (Fig. 1). Replacement of RPMI 1640 by MGB had no influence on these results. The time course seen with a bolus of $5 \mathrm{mM} \mathrm{H}_{2} \mathrm{O}_{2}$ was similar to that observed when using a dilution of glucose oxidase $(4.5 \mathrm{mU})$, which continuously produced $1.1 \mu \mathrm{M} \mathrm{H}_{2} \mathrm{O}_{2} / \mathrm{min}$ (data not shown). At a cell concentration of $2 \times 10^{6} / \mathrm{ml}$, the $\mathrm{H}_{2} \mathrm{O}_{2}$ disappeared with a half-life of $17 \mathrm{~min}$. Depletion of $90-95 \%$ of the cellular glutathione by incubation with $0.2 \mathrm{mM}$ BSO (16) for $18 \mathrm{~h}\left(\mathrm{t}^{1 / 2}\right.$ of depletion $\left.=4.5 \mathrm{~h}\right)$ induced earlier ${ }^{51} \mathrm{Cr}$ release than seen in cells with normal glutathione levels (Fig. 1). With high concentrations of $\mathrm{H}_{2} \mathrm{O}_{2}(>1 \mathrm{mM}),{ }^{51} \mathrm{Cr}$ release at later time points (e.g., $4 \mathrm{~h}$ for $5 \mathrm{mM} \mathrm{H}_{2} \mathrm{O}_{2}$; see Fig. 1) approached similar values for normal and GSH-depleted cells. Lower concentrations of

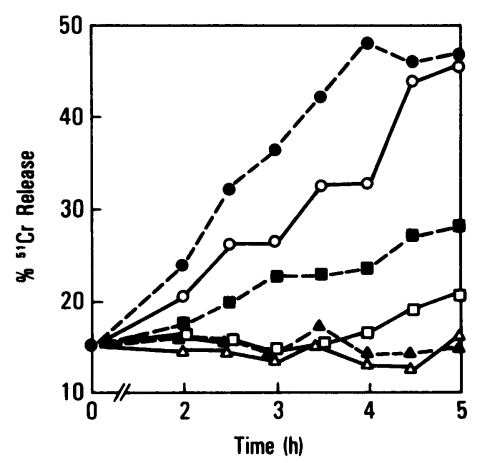

Figure $1 .{ }^{51} \mathrm{Cr}$ release from P388D1 cells incubated in RPMI 1640 after exposure to $\mathrm{H}_{2} \mathrm{O}_{2}$ in a concentration range between 0.5 and 5 $\mathrm{mM} \mathrm{H} \mathrm{H}_{2} \mathrm{O}_{2}$ in normal cells (GSH: $2.0 \pm 0.65 \mathrm{nmol}$ $\mathrm{GSH} / 10^{6}$ cells) (-) and BSO-treated cells (GSH: $0.17 \pm 0.05 \mathrm{nmol} \mathrm{GSH} / 10^{6}$ cells) (--.--); mean of three experiments. Concentrations of 1 and $2.5 \mathrm{mM}$ $\mathrm{H}_{2} \mathrm{O}_{2}$ showed similar results not shown here. $\triangle$, Control; $\triangle$, BSO-treated control; o, $5 \mathrm{mM} \mathrm{H}_{2} \mathrm{O}_{2}$; •, $5 \mathrm{mM} \mathrm{H}_{2} \mathrm{O}_{2}$ in BSO-treated cells; $\square, 0.5 \mathrm{mM} \mathrm{H}_{2} \mathrm{O}_{2}$; and $\mathrm{a}, 0.5 \mathrm{mM}$ $\mathrm{H}_{2} \mathrm{O}_{2}$ in BSO-treated cells. 


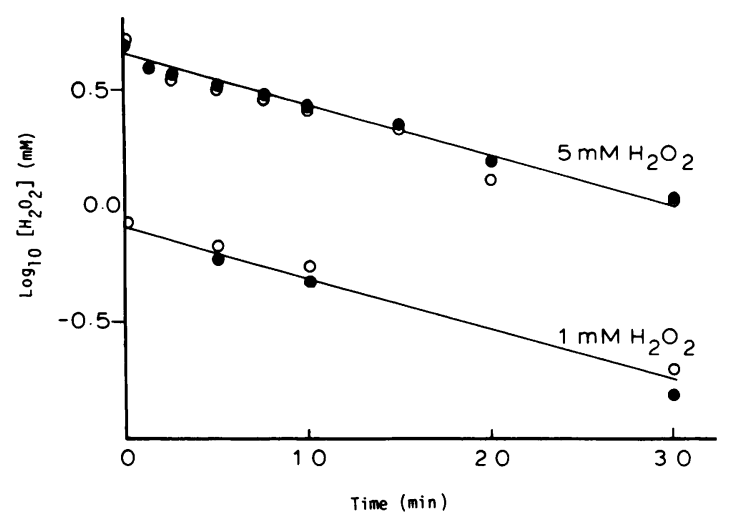

Figure 2. Concentration of $\mathrm{H}_{2} \mathrm{O}_{2}$ in the supernatant of $2 \times 10^{6} / \mathrm{ml}$ P388D1 cells incubated with 1 or $5 \mathrm{mM} \mathrm{H}_{2} \mathrm{O}_{2}$. The closed circles show normal cells, and the open circles show cells that were depleted of $92 \%$ of their glutathione.

$\mathrm{H}_{2} \mathrm{O}_{2}$ induced a higher percentage of cell lysis in $\mathrm{GSH}$-depleted cells until the latest time point tested $(7 \mathrm{~h})$. The disappearance of $\mathrm{H}_{2} \mathrm{O}_{2}$ measured fluorometrically was not influenced by BSO treatment (Fig. 2). The difference in cell lysis induced by BSO treatment of the cells suggested that glutathione was important in protection of the target cells from oxidants under our experimental conditions. This confirmed data obtained in various other systems $(4,5)$.

Catalase in a concentration $(5,000 \mathrm{U} / \mathrm{ml})$ that completely removed $5 \mathrm{mM} \mathrm{H}_{2} \mathrm{O}_{2}$ within $<30 \mathrm{~s}$, could rescue the cells only if added during the first 20-30 min. If added during this period of time, cells were completely rescued, with ${ }^{51} \mathrm{Cr}$ release as in control cells. When catalase was added at $45 \mathrm{~min}$, no protection from lysis was observed.

Effect of oxidants on reduced, oxidized, and protein-bound glutathione in the target cells. Since normal intracellular gluta- thione levels partially protected against cell lysis, we determined glutathione concentrations and redox state after exposure to $\mathrm{H}_{2} \mathrm{O}_{2}$. Total glutathione levels in control cells averaged $2 \mathrm{nmol} /$ $10^{6}$ cells, ranging from 1 to $3 \mathrm{nmol}$ in different experiments. Addition of $2.5 \mathrm{mM} \mathrm{H}_{2} \mathrm{O}_{2}$ caused an immediate small increase in GSSG, from 0.05 to $3 \%$ of total glutathione content, which gradually increased up to $20 \%$ during the first hour (Table I). In these cells, total glutathione levels decreased by $<5 \%$ during this period of time.

In order to determine whether the low concentration of GSSG was due to a high rate of enzymatic reduction, cells were incubated with $\mathrm{H}_{2} \mathrm{O}_{2}$ at $4^{\circ} \mathrm{C}$. When exposed to $2.5 \mathrm{mM} \mathrm{H}_{2} \mathrm{O}_{2}$ at $4^{\circ} \mathrm{C}$, intracellular glutathione of $\mathrm{P} 388 \mathrm{D} 1$ cells was totally oxidized nonenzymatically within $10 \mathrm{~min}$ (Table I). Assuming that the high rate of glutathione cycle activity in P388D1 cells can only be achieved when NADPH is constantly replenished by a very active HMPS (see Fig. $9 A$ ), GSSG should not be as quickly reduced in a cell with low HMPS activity. For this purpose, human erythrocytes that form $\sim 4 \mathrm{pmol} \mathrm{CO} / 10^{6}$ cells per min (27) were chosen for comparison. With human erythrocytes, glutathione was completely oxidized at $\sim 2 \mathrm{~min}$; this was followed by gradual rereduction (Table I), presumably by HMPS activity, at time points when all the $\mathrm{H}_{2} \mathrm{O}_{2}$ had been consumed. Approximately $20 \%$ of the total glutathione was irreversibly lost from the cell within $1 \mathrm{~h}$. All $\mathrm{H}_{2} \mathrm{O}_{2}$ in the extracellular medium of the erythrocytes was removed within $1 \mathrm{~min}$.

If it is true that GSSG is reduced in P388D1 cells at a rate that prevents its accumulation, inhibition of the HMPS should cause an increase in GSSG. In order to evaluate this hypothesis, P388D1 cells were exposed to $\mathrm{H}_{2} \mathrm{O}_{2}$ in the absence of glucose as a means to inhibit the HMPS. Under these conditions, P388D1 cells behaved similarly to the erythrocytes, except that GSSG never accounted for $>70 \%$ of total glutathione moiety (Table I). Even before the addition of oxidant, there was a change in the GSSG/GSH ratio from approximately $1: 2,000$ to $1: 25$

Table I. Oxidation of Glutathione After Exposure to $\mathrm{H}_{2} \mathrm{O}_{2}{ }^{*}$

\begin{tabular}{|c|c|c|c|c|c|c|}
\hline \multirow[b]{3}{*}{ Time } & \multicolumn{5}{|c|}{ P388D1 cells } & \multirow[b]{3}{*}{$\mathbf{R B C}$} \\
\hline & & & Second bolus & & Four degrees & \\
\hline & & + Glucose & $\mathrm{H}_{2} \mathrm{O}_{2}$ at $20^{\prime}$ & - Glucose & + Glucose & \\
\hline \multicolumn{7}{|l|}{$\min }$. \\
\hline Control & & 0.05 & & 3.9 & 0.05 & 4.8 \\
\hline 1 & & 3.7 & & 68.9 & - & 94.4 \\
\hline 2.5 & & 4.7 & & 53.5 & 26.2 & 100.0 \\
\hline 5 & & 4.7 & & 48.8 & 48.0 & 64.2 \\
\hline 10 & & 5.2 & & 31.1 & 100.0 & 43.4 \\
\hline \multirow[t]{2}{*}{15} & & 7.1 & & & & \\
\hline & & & & 27.5 & 103.2 & 29.7 \\
\hline 20 & 7.9 & & -66.0 & 24.0 & 98.6 & 21.7 \\
\hline 30 & 11.0 & & 70.1 & 20.0 & - & 12.5 \\
\hline 45 & 16.6 & & 69.2 & 13.8 & - & 6.8 \\
\hline 60 & 21.7 & & 70.5 & 14.7 & - & 7.1 \\
\hline
\end{tabular}

\footnotetext{
* Results are expressed as GSSG as a percentage of total acid-soluble glutathione. GSSG was determined enzymatically (mean of three experiments) after exposure of $(a) 2 \times 10^{6} \mathrm{P} 388 \mathrm{Dl}$ cells \pm glucose at $37^{\circ}$ or $4^{\circ} \mathrm{C}$ (total glutathione expressed as GSH equivalent: $2 \mathrm{nmol} / 10^{6} \mathrm{cells}$ ), and (b) $2 \times 10^{7} / \mathrm{ml}$ human erythrocytes (total glutathione: $0.54 \mathrm{nmol} / 10^{6}$ cells) to $2.5 \mathrm{mM} \mathrm{H}_{2} \mathrm{O}_{2}$. In two experiments, P388D1 cells in the presence of glucose were exposed to a second bolus of $2.5 \mathrm{mM} \mathrm{H}_{2} \mathrm{O}_{2}$ at $20 \mathrm{~min}$, as shown in the second column.
} 
when there was no glucose in the incubation medium. No influence in cell viability was observed until 60 min of $\mathrm{H}_{2} \mathrm{O}_{2}$ exposed. A dose response measuring oxidation of glutathione in the absence of glucose $1 \mathrm{~min}$ after exposure to $\mathrm{H}_{2} \mathrm{O}_{2}$ showed that while $\sim 5 \mathrm{mM} \mathrm{H}_{2} \mathrm{O}_{2}$ is needed for maximal oxidation, a dose of $10 \mu \mathrm{M}$ is sufficient to oxidize $18 \%$ of the glutathione (Fig. 5). Similar results were seen in human erythrocytes in the presence of glucose.

Another way of assessing the dependence of GSSG reduction on an active HMPS was to add a second bolus of $\mathrm{H}_{2} \mathrm{O}_{2}$ at a time after initial injury, when the HMPS is no longer functioning. When P388D1 cells treated with $2.5 \mathrm{mM} \mathrm{H}_{2} \mathrm{O}_{2}$ in the presence of glucose were exposed to a second bolus of $\mathrm{H}_{2} \mathrm{O}_{2}$ at $20 \mathrm{~min}$, i.e., at a time when the pentose phosphate shunt was completely inhibited (see Fig. $9 \mathrm{~A}$ ), $70 \%$ of the cellular glutathione was oxidized immediately and could not be rereduced.

It has been described for various cell types $(9,28,29)$ that GSSG is transported out of the cell. Under our experimental conditions, this was not the case to any large degree. In P388D1 cells exposed to $2.5 \mathrm{mM} \mathrm{H}_{2} \mathrm{O}_{2}$ in the absence of glucose, very little efflux of GSSG into the extracellular medium was measured with $<10 \%$ of the total glutathione moiety being released into the incubation medium within $1 \mathrm{~h}$ (Fig. 3). On the other hand, if GSH was oxidized with $100 \mu \mathrm{M}$ diamide in the absence of glucose to the same level as with $\mathrm{H}_{2} \mathrm{O}_{2}$, GSSG was lost from the cell at a rate of $\sim 1 \% \mathrm{~min}^{-1}$ during the first $30 \mathrm{~min}$.

With only $1 \%$ of the total glutathione found in the extracellular medium 5 min after exposure of P388D1 cells to $5 \mathrm{mM}$ $\mathrm{H}_{2} \mathrm{O}_{2}$ in the absence of glucose, we determined the disposition of glutathione within the cells after exposure to $\mathrm{H}_{2} \mathrm{O}_{2}$. It was found that there was a rapid, partial disappearance of total acidsoluble glutathione (33\% at $10 \mathrm{~min})$; it returned during the following $20 \mathrm{~min}$ (Fig. 3). To examine whether the lost glutathione was bound to protein, cells were prelabeled with $\left[{ }^{35} \mathrm{~S}\right]$ cysteine, $90 \%$ of which was incorporated into GSH (see Methods). 5 $\times 10^{6}$ prelabeled cells were exposed to $5 \mathrm{mM} \mathrm{H}_{2} \mathrm{O}_{2}$ and then assessed for the presence of ${ }^{35} \mathrm{~S}$ in the perchloric acid supernatant and the precipitated protein. An increase of radioactivity in the acid-precipitated protein pellet was noticed. By $10 \mathrm{~min}, 25 \%$ of the radiolabel was found in the acid precipitate. When the acid precipitate was resuspended in DTT containing buffer (20), an amount of GSH (as measured by either absorbance or radioactivity in HPLC), which was almost identical to the loss from the supernatant after acid precipitation, could be recovered from

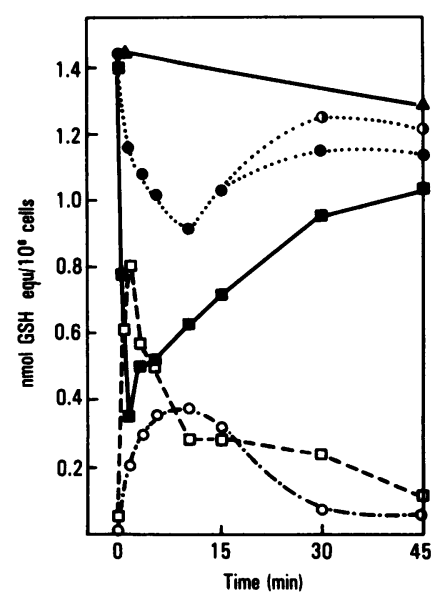

Figure 3. Quantitation of reduced ( $\square$ ), oxidized-free ( $\square$ ), and protein-bound $(0)$ glutathione after exposure of $5 \times 10^{6}$ P388D1 cells/ml to $5 \mathrm{mM}$ $\mathrm{H}_{2} \mathrm{O}_{2}$ in MGB in the absence of glucose (mean of two experiments). Total acid soluble glutathione was determined enzy-

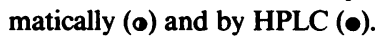
(4) Total acid-soluble glutathione in P388D1 cells not exposed to $\mathrm{H}_{2} \mathrm{O}_{2}$.

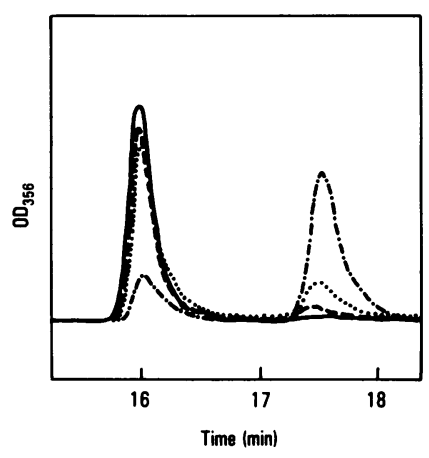

Figure 4. HPLC tracing for GSH and GSSG. Samples were prepared as described in Methods. Retention time for GSH was $16.0 \mathrm{~min}$, and for GSSG 17.7 min: (a) (- - -) P388D1 cells; $(b)(\cdots)$ P388D1 cells plus $5 \mathrm{mM} \mathrm{H}_{2} \mathrm{O}_{2}, 1$ min at $37^{\circ} \mathrm{C}, 1,1.0 \mathrm{mg} / \mathrm{ml}$ glucose; $(c)$ $(-\cdot-\cdot-) \mathrm{P} 388 \mathrm{D} 1$ cells plus 5 $\mathrm{mM} \mathrm{H} \mathrm{H}_{2} \mathrm{O}_{2}, 1$ min at $37^{\circ} \mathrm{C}, 1$ in the absence of glucose; and $(d)$ $(\longrightarrow)$ same as $(c)$ after reduction with $2 \mathrm{mM}$ DTT.

the precipitated protein moieties (Fig. 4). Maximal protein disulfide formation was preceded by maximal GSSG formation. As total free glutathione levels increased again, in the period from 15 to 30 min after exposure to $\mathrm{H}_{2} \mathrm{O}_{2}$, glutathione binding to protein gradually disappeared.

$\mathrm{NADPH}$ levels after exposure to $\mathrm{H}_{2} \mathrm{O}_{2}$. Since a conversion of GSH to GSSG, followed by reduction to GSH, occurred rapidly upon exposure of cells to oxidants, experiments were undertaken to determine if this affected the turnover of NADPH and NADP. A bolus of $2.5 \mathrm{mM} \mathrm{H}_{2} \mathrm{O}_{2}$ induced an instantaneous drop in NADPH levels from 55 to 22 pmol/10 $10^{6}$ cells in $\sim 10$ (Fig. 5). NADPH did not decrease further during the course of the injury and, indeed, gradually increased over $50 \mathrm{~min}$ (Fig. 6 $B)$. Levels of NADP (12 pmol/10 $10^{6}$ cells) did not increase simultaneously, which lead to a drop in total NADP plus NADPH (Fig. 7). NADPH/NADPH plus NADP ratios dropped from 0.82 to 0.62 within $2 \mathrm{~min}$, and gradually increased again.

To determine if the fall in NADPH was related to the oxidation and reduction of glutathione, $2.5 \mathrm{mM} \mathrm{H}_{2} \mathrm{O}_{2}$ was added to cells preincubated with $\mathrm{BCNU}$ for $10 \mathrm{~min}$. As shown in Fig. $6 \mathrm{~B}$, the initial loss of NADPH was prevented. Similar results were obtained when glutathione synthesis had been inhibited with BSO (glutathione levels depleted by 92\%) (Fig. $6 \mathrm{~B}$ ). Both these results indicated that NADPH is used for the reduction of GSSG by glutathione reductase. Over a longer period of time (10-50 min), BSO or BCNU-treated cells exposed to $\mathrm{H}_{2} \mathrm{O}_{2}$ showed a continuous decrease in NADPH, to levels that were

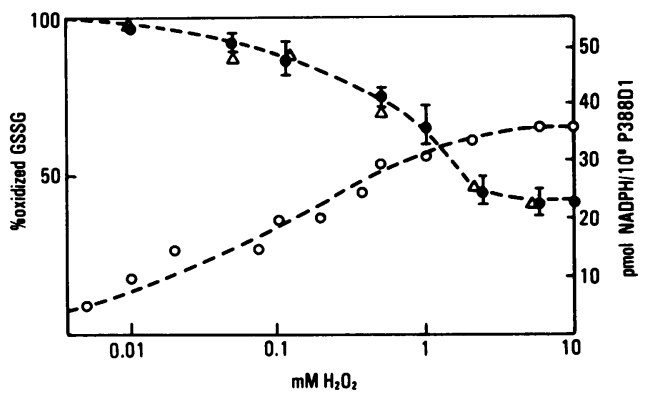

Figure 5. Response of glutathione and NADP(H) in P388D1 cells incubated in MGB 1 min after exposure to varying doses of $\mathrm{H}_{2} \mathrm{O}_{2}$. Percentage of GSSG and picomoles NADPH/10 6 P388D1 cells (mean and SD of three experiments) 1 min after exposure to $\mathrm{H}_{2} \mathrm{O}_{2}$ in the presence and absence of glucose. $(O)$ Percentage of GSSG in the absence of glucose; (๑) picomoles NADPH in the presence of glucose; and $(\Delta)$ picomoles NADPH in the absence of glucose. 

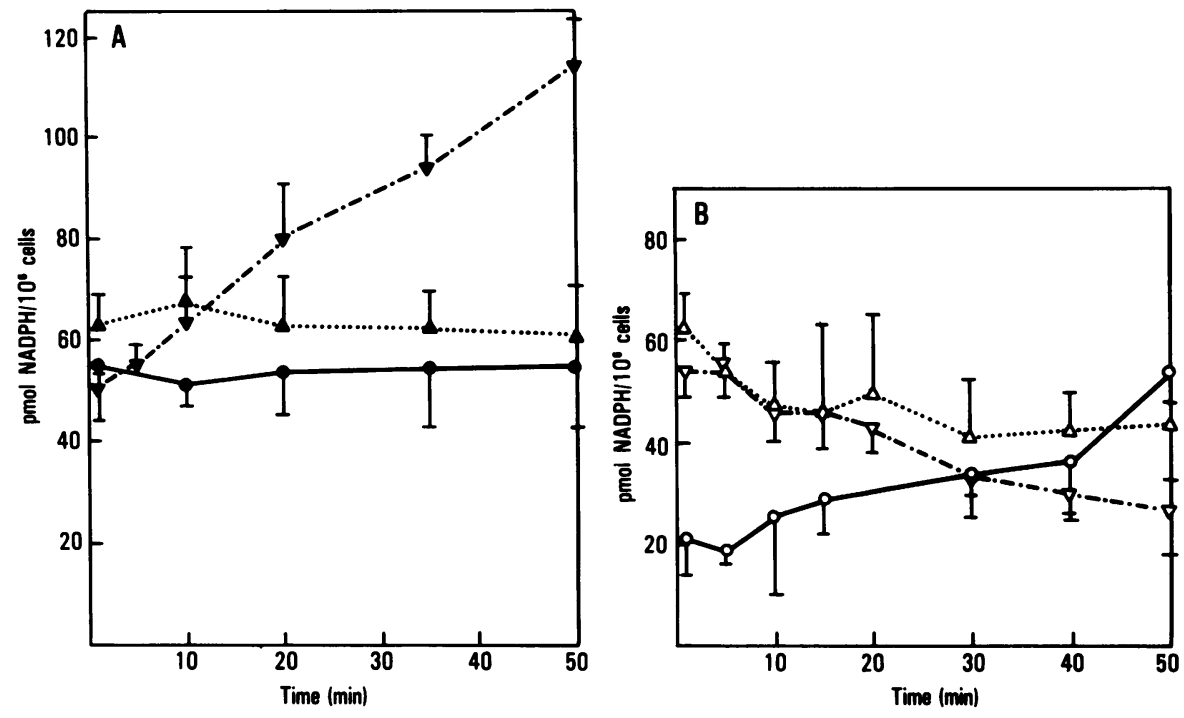

Figure 6. Concentration of NADPH in $\mathrm{P} 388 \mathrm{D} 1$ cells incubated in $\mathrm{MGB}$ in the presence and absence of $2.5 \mathrm{mM} \mathrm{H}_{2} \mathrm{O}_{2}$, which was added at 0 min, mean and SD of three experiments. $(A)(\bullet)$ Control cells; $(\Delta \cdots \cdots \Delta)$ control cells, BSO treated $\left(0.12 \pm 0.03 \mathrm{nmol} \mathrm{GSH} / 10^{6}\right.$ cells $)$; and $(\nabla-\cdot-\cdot \cdot-\nabla)$ control cells exposed at 75 $\mu \mathrm{M}$ BCNU at -5 min. (B) (O) Cells exposed to $2.5 \mathrm{mM} \mathrm{H}_{2} \mathrm{O}_{2} ;(\Delta \cdots \Delta)$ BSO-treated cells exposed to $2.5 \mathrm{mM} \mathrm{H}_{2} \mathrm{O}_{2} ;(\nabla-\cdot-\cdot-\nabla)$ BCNU-treated cells (at $-10 \mathrm{~min}$ ) exposed to $2.5 \mathrm{mM} \mathrm{H}_{2} \mathrm{O}_{2}$.

lower than those in nontreated cells at $\sim 50$ min (Fig. $6 \mathrm{~B}$ ). At the same time there was a gradual increase in NADP, leaving the amount of total NADP(H) moiety constant (Fig. 7). The ratio NADPH/NADPH plus NADP was almost identical in BSO and BCNU-treated cells. The slow oxidation of NADPH under these conditions might have been due to residual glutathione cycle activity.

When a small amount of $\mathrm{H}_{2} \mathrm{O}_{2}$ was produced continuously with glucose oxidase-glucose $\left(2 \mu \mathrm{M} \mathrm{min}{ }^{-1}\right)$, NADPH levels changed very little, while NADP increased, leading to a small increase in total NADP $(\mathrm{H})$ moiety.

Since total NADP $(\mathrm{H})$ moiety disappeared after exposure of P388D1 cells to $\mathrm{H}_{2} \mathrm{O}_{2}$ in the presence of an activated HMPS, we followed changes in the total pyridine nucleotide pool. For this purpose, cells were labeled with ${ }^{14} \mathrm{C}$-nicotinic acid, and the labeled compounds were separated by TLC or HPLC (see Methods). $85 \%$ of the intracellular ${ }^{14} \mathrm{C}$-nicotinic acid was recovered as $\mathrm{NAD}(\mathrm{P})$ moiety as determined by separation of ethanol ex-

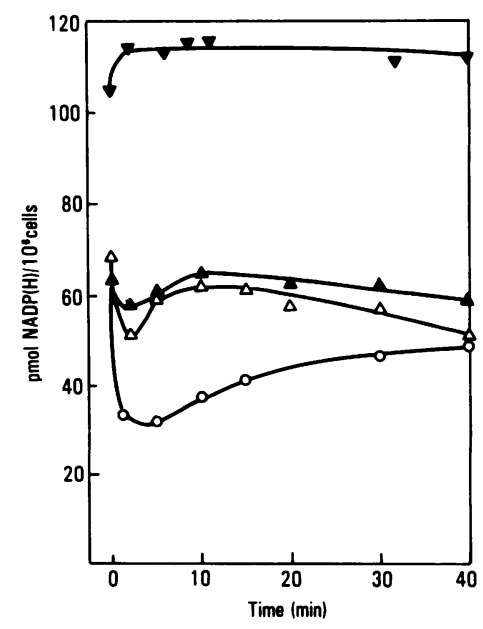

Figure 7. Concentration of NADPH plus NADP in P388D1 cells exposed to: (O) $2.5 \mathrm{mM} \mathrm{H}_{2} \mathrm{O}_{2} ;(\Delta) 2.5 \mathrm{mM} \mathrm{H}_{2} \mathrm{O}_{2}$ in the absence of glucose; (ム) BSO-treated cells ( $92 \%$ glutathione depleted), plus $2.5 \mathrm{mM}$ $\mathrm{H}_{2} \mathrm{O}_{2}$; and (v) cells treated with $75 \mu \mathrm{M}$ BCNU 30 min before the addition of $2.5 \mathrm{mM} \mathrm{H}_{2} \mathrm{O}_{2}$. tracts on TLC. The initial distribution of radiolabel was $50 \%$ NAD, $17 \%$ NADH, 13\% NADPH, and 5\% NADP. In the presence of $2.5 \mathrm{mM} \mathrm{H}_{2} \mathrm{O}_{2}$, an increased turnover of radiolabeled pyridine nucleotides occurred. Not only did ${ }^{14} \mathrm{C}-\mathrm{NADPH}$ decrease immediately and continuously, but ${ }^{14} \mathrm{C}$-NAD decreased to an even larger degree (Fig. 8). Absolute amounts of NAD as determined by HPLC (24) decreased from $1.35 \mathrm{nmol} / 10^{6}$ cells to $0.28 \mathrm{nmol} / 10^{6}$ cells $20 \mathrm{~min}$ after addition of $2.5 \mathrm{mM} \mathrm{H}_{2} \mathrm{O}_{2}$. Initially, radioactive NADH and NADP increased slightly. After 2 to $3 \mathrm{~min},{ }^{14} \mathrm{C}-\mathrm{NADH}$ started to drop slightly, while NADP stayed constant. In data to be reported separately, a dose of 50 $\mu \mathrm{M} \mathrm{H}_{2} \mathrm{O}_{2}$ was found to lead to maximal NAD depletion. As noted in the Discussion, the observed fall in NAD may be of considerable significance in the injury of cells by oxidants.

Nicotinamide or nicotinic acid did not accumulate intracellularly. $5 \mathrm{~min}$ after exposure to $\mathrm{H}_{2} \mathrm{O}_{2}, 30 \%$ of the radiolabel appeared in the supernatant, and at $20 \mathrm{~min}, 76 \%$ was in the supernatant of the cells. Pretreatment of cells with BSO did not have any influence on the loss of ${ }^{14} \mathrm{C}$-pyridine moiety from

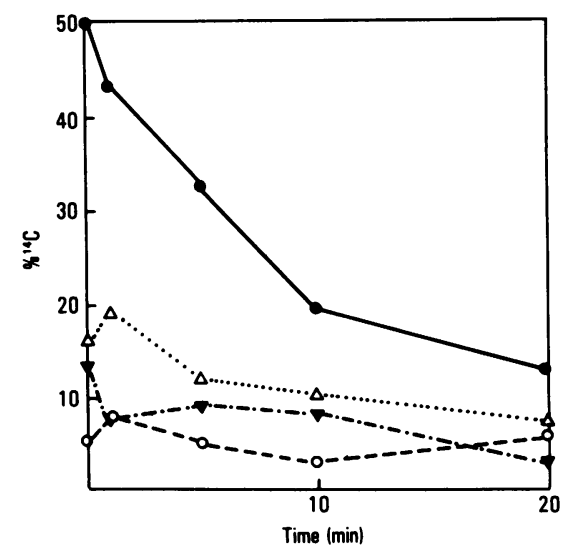

Figure 8. Percentage of initial radioactivity in different ${ }^{14} \mathrm{C}$-nicotinic acid-labeled pyridine nucleotide moieties in $2 \times 10^{6} / \mathrm{ml} \mathrm{P388D1}$ cells incubated in RPMI 1640 plus $2.5 \mathrm{mM} \mathrm{H}_{2} \mathrm{O}_{2}$. (•) NAD; $(\Delta) \mathrm{NADH}$; ( $\nabla$ ) NADPH; and (O) NADP. Mean of two experiments. In control cells not exposed to $\mathrm{H}_{2} \mathrm{O}_{2}$, NAD dropped by $12 \%$ over $20 \mathrm{~min}$; the other compounds were not influenced. 
P388D1 cells exposed to $\mathrm{H}_{2} \mathrm{O}_{2}$. The radioactivity of the supernatant, when chromatographed on a C18 column in HPLC, coeluted with a known sample of nicotinamide. An equally large loss of pyridine moiety into the supernatant occurred with as little as $50 \mu \mathrm{M} \mathrm{H}_{2} \mathrm{O}_{2}$. Control cells lost only $12 \%$ of the radiolabel during this period of time.

Influence of $\mathrm{H}_{2} \mathrm{O}_{2}$ on HMPS activity. The reduction of GSSG to GSH requires considerable amounts of NADPH. We therefore examined the major reductive pathway of NADP, the HMPS. Uninjured P388D1 cells formed a large amount of $\mathrm{CO}_{2}-\sim 120$ pmol CO $2 / \mathrm{min} \times 10^{6}$ cells-by the HMPS (see Methods). $\mathrm{CO}_{2}$ formation from the HMPS exceeded $\mathrm{CO}_{2}$ formation in the TCA cycle by $\sim 10$-fold. After exposure to $2.5 \mathrm{mM} \mathrm{H}_{2} \mathrm{O}_{2}$, HMPS activity was activated about sixfold during the first $2 \mathrm{~min}$ and about threefold during the first $15 \mathrm{~min}(390 \mathrm{pmol} \mathrm{CO} / \mathrm{min}$ $\times 10^{6}$ cells) (Fig. $9 \mathrm{~A}$ ). Eventually, HMPS activity was completely abolished, with doses of $\mathrm{H}_{2} \mathrm{O}_{2}$ of $500 \mu \mathrm{M}$ and more.

To determine if the stimulation of the HMPS by exposure of cells to $\mathrm{H}_{2} \mathrm{O}_{2}$ acted through the glutathione-NADPH cycle, intracellular glutathione was depleted by $92 \%$ with BSO. Exposure of these cells to $2.5 \mathrm{mM} \mathrm{H}_{2} \mathrm{O}_{2}$ produced only a slight increase in HMPS activity, considerably less than in cells with normal glutathione levels (Fig. $9 \mathrm{~B}$ ). Similar results were seen in BCNU-treated cells: before the addition of $\mathrm{H}_{2} \mathrm{O}_{2}$, no change in pentose phosphate shunt activity was observed, while addition of $\mathrm{H}_{2} \mathrm{O}_{2}$ completely inhibited the formation of $\mathrm{CO}_{2}$ in the HMPS (Fig. 9 B).

\section{Discussion}

Biochemical events important in the lethal injury of cells induced by oxidants were found to take place in the initial $30 \mathrm{~min}$ of exposure of the target cells to the oxidant. Removal of $\mathrm{H}_{2} \mathrm{O}_{2}$ during this period of time completely prevented cell lysis within a time period of $7 \mathrm{~h}$. Removal of $\mathrm{H}_{2} \mathrm{O}_{2}$ at any later time point failed to show any protective effect. We therefore have attempted to elucidate changes occurring in the biochemistry of the target cell during this early period. After exposure of cells to $\mathrm{H}_{2} \mathrm{O}_{2}$, an
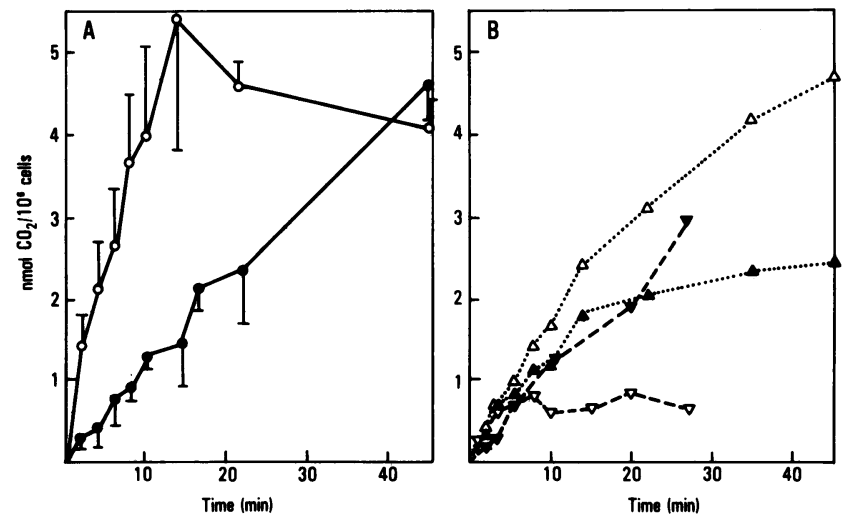

Figure 9. HMPS activity in P388D1 cells $\left(2 \times 10^{6} / \mathrm{ml}\right.$ in MGB, 5.5 $\mathrm{mM}$ glucose). Data were calculated as the difference between ${ }^{14} \mathrm{CO}_{2}$ generated from $\mathrm{C}_{1}$ - vs. $\mathrm{C}_{6}$-labeled glucose. $(A)(\bullet) \mathrm{P} 388 \mathrm{D}_{1}$ cells, no $\mathrm{H}_{2} \mathrm{O}_{2}$; and (O) $\mathrm{P} 388 \mathrm{D}_{1}$ cells plus $2.5 \mathrm{mM} \mathrm{H}_{2} \mathrm{O}_{2}$ (mean and $\mathrm{SD}$ of four experiments). (B) $(\Delta \cdots \Delta)$ BSO-treated cells, no $\mathrm{H}_{2} \mathrm{O}_{2} ;(\Delta \cdots \Delta)$ BSOtreated cells plus $2.5 \mathrm{mM} \mathrm{H}_{2} \mathrm{O}_{2} ;(\nabla-\ldots--\nabla)$ cells incubated with $\mathrm{BCNU}$. for $30 \mathrm{~min}$ at $37^{\circ} \mathrm{C}$; and $(\nabla----\nabla) \mathrm{BCNU}$-treated cells plus $2.5 \mathrm{mM}$ $\mathrm{H}_{2} \mathrm{O}_{2}$; data represent the mean of two experiments. increase of oxidative turnover of GSH and NADPH was found to be an early event, detectable within a few seconds of exposure of the cells to the oxidant. They precede the fall in intracellular ATP reported that was recently from this laboratory (25). ATP levels decreased within a few minutes and, with $5 \mathrm{mM} \mathrm{H}_{2} \mathrm{O}_{2}$, dropped to $10-20 \%$ of normal within $10 \mathrm{~min}$.

For purposes of the discussion, the relationships of components of the glutathione reduction-oxidation cycle are illustrated in Scheme 1. The dependence of the glutathione redox

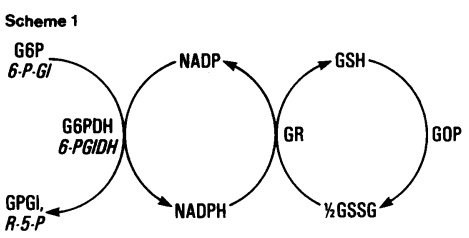

Scheme 1. GOP, glutathione peroxidase; GR, glutathione reductase; G6P, glucose-6-phosphate; GPGl, glucose-6-phosphogluconate; G6PDH, glucose-6phosphate dehydrogenase;

6-P-Gl, 6-phosphogluconate; 6-PGLDH, 6-phosphogluconate dehydrogenase; R-5-P-, D-ribulose-5-phosphate.

cycle upon reducing equivalents produced by the pentose phosphate shunt (HMPS) becomes clear when one takes into account the actual concentration of GSH, GSSG, NADP(H), and the activity of the HMPS in P388D1 cells. P388D1 cells contain enough glutathione reductase to reduce $3.9 \mathrm{nmol} \mathrm{GSSG} / 10^{6}$ cells per min (1), which is fourfold their total content in GSSG equivalent. Their glutathione peroxidase content is again 10-fold higher (1). GSH (1.1 mM, expressed as GSSG equivalents) exists in 35-fold excess over NADPH (31 $\mu \mathrm{M})$. The rate-limiting factor thus becomes the amount of NADPH that is available for glutathione reduction. NADPH, which never decreased by $>60 \%$, is replenished by the HMPS, which we found to produce 0.12 $\mathrm{nmol} \mathrm{CO} 2 / 10^{6}$ cells per min in resting $\mathrm{P} 388 \mathrm{D} 1$ cells, and which is increased sixfold by $2.5 \mathrm{~min}$ after addition of $2.5 \mathrm{mM} \mathrm{H}_{2} \mathrm{O}_{2}$. This stimulation of the HMPS would yield $1.44 \mathrm{nmol} \mathrm{NADPH/}$ min per $10^{6}$ cells from NADP. This amount of NADPH production would allow conversion of GSSG to GSH at the rate of 1.5 times the total glutathione content $(\sim 1 \mathrm{nmol}$ GSSG equivalents $/ 10^{6}$ cells) of the cells per minute. We presume this to be sufficient to maintain the glutathione in the reduced form during the early stages of oxidant injury. The importance of the HMPS in maintaining reducing equivalents for the cell was observed when cells with diminished HMPS activity were exposed to oxidant: (a) In the absence of glucose, HMPS activity was greatly inhibited, and GSSG accumulated rapidly. (b) In cells exposed to $\mathrm{H}_{2} \mathrm{O}_{2}$ in the presence of glucose, HMPS activity was lost by 15 min after exposure of cells to $\mathrm{H}_{2} \mathrm{O}_{2}$ (Fig. 9). When a second bolus of $\mathrm{H}_{2} \mathrm{O}_{2}$ was given at this time, GSSG again accumulated. (c) Exposure of $\mathrm{P} 388 \mathrm{D} 1$ cells to $\mathrm{H}_{2} \mathrm{O}_{2}$ at $4^{\circ} \mathrm{C}$ showed that intracellular GSH could be irreversibly (and nonenzymatically) oxidized when the HMPS was inactivated. $(d)$ In erythrocytes, which do not possess a highly active HMPS (27) and therefore do not have the capacity to produce as much NADPH as the P388D1 cells, $\mathrm{H}_{2} \mathrm{O}_{2}$ causes a rapid and complete oxidation of glutathione.

Our studies support the concept that the oxidation of NADPH induces activity of the HMPS. Depletion of GSH by inhibition of its synthesis with BSO-which was developed as a specific inhibitor of gamma glutamylcysteine synthetase (16)largely reduced the activation of the HMPS when cells were exposed to oxidants (Fig. 9). In addition, inhibition of glutathione reductase by BCNU (28) completely inhibited the activation of 
the HMPS. Under these conditions, the immediate conversion of NADPH to NADP did not take place during exposure of the cells to $\mathrm{H}_{2} \mathrm{O}_{2}$.

Upon exposure of the P388D1 cells to $\mathrm{H}_{2} \mathrm{O}_{2}$, GSSG was not transported to the cell exterior, as has been described for several other cells $(7,9,28)$. Incubation of P388D1 cells with $100 \mu \mathrm{M}$ diamide leads to a $30 \%$ loss of total intracellular glutathione recovered as GSSG extracellularly, which indicates that GSSG can escape these cells. Since GSSG translocation is an ATPdependent process (9), its loss from the cells may be inhibited because of the substantial loss of ATP sustained by these cells in the presence of $\mathrm{H}_{2} \mathrm{O}_{2}$ (25).

From our results, as well as from earlier reports $(4,5)$, we conclude that $\mathrm{GSH}$ partially protects cells from $\mathrm{H}_{2} \mathrm{O}_{2}$-induced cell lysis, especially at threshold doses of $\mathrm{H}_{2} \mathrm{O}_{2}(500 \mu \mathrm{M})$ that did not induce a substantial amount of cell lysis in cells with normal gluathione content. Depletion of glutathione did not interfere with the capacity of the cell to remove $\mathrm{H}_{2} \mathrm{O}_{2}$ from the extracellular medium. Therefore, $\mathrm{H}_{2} \mathrm{O}_{2}$, though initiating the events leading to cell lysis, does not seem to be the only oxidant involved in cellular death. GSH may act either by protecting cells from lipid peroxidation (30) due to secondarily formed oxygen radicals, or by protecting protein sulfhydryls from becoming irreversibly oxidized after oxidant injury $(31,32)$. Similarly, mixed disulfides can be formed between protein and glutathione $(11,33)$. It has been shown for several enzyme systems (34-38) that these mixed disulfides can alter various enzyme functions. In contrast to intermolecular disulfides between proteins, the mixed disulfides between protein and glutathione can be cleaved by glutathione reductase as well as thiol transferases, which reverses the impairment of the enzyme function.

An additional explanation for the protective role of intracellular GSH is that it is not only protective by itself, but that intermediates of the activated HMPS are involved in cell protection. Production of ribose-5-phosphate, which is needed for nucleic acid synthesis, could be important for DNA repair, which ought to be augmented after exposure to oxidant, since both $\mathrm{H}_{2} \mathrm{O}_{2}$ and $\mathrm{O}_{2}^{-}$are known to induce DNA damage (39-42).

Total NADP(H) moiety decreased after exposure of P388D1 cells to $\mathrm{H}_{2} \mathrm{O}_{2}$ in the presence of an activated HMPS. The loss of NAD and NADP $(H)$ occurred independently: the loss of total NADP $(\mathrm{H})$ was prevented by inhibition of the HMPS (BSO and BCNU-treated cells), and was diminished in the absence of glucose. Under these conditions, NAD levels fell at the same rate as in normal cells that were exposed to $\mathrm{H}_{2} \mathrm{O}_{2}$ (unpublished data). In addition, as will be published separately, inhibition of the fall in NAD failed to prevent the NADP-dependent stimulation of the HMPS. The loss of $80 \%$ of total pyridine nucleotide moiety, as determined by radiolabel, after exposure of $\mathrm{P} 388 \mathrm{D} 1$ cells that were exposed to as little as $50 \mu \mathrm{M} \mathrm{H}_{2} \mathrm{O}_{2}$, was quite unexpected. It could not be explained by nonspecific plasma membrane leakiness, since no increase in permeability was noticed for other small solutes $\left(\mathrm{K}^{+}\right.$, aminoisobutyric acid, UDP-glucose) during the first $20 \mathrm{~min}$, nor was extracellular NAD taken up by these cells. Since the lost intracellular radiolabeled pyridine nucleotide could be quantitatively recovered in the supernatant-co-eluting with nicotinamide in TLC and HPLC-increased catabolism of NAD seems to be the most direct explanation. The catabolism of NAD and NADP is regulated by poly(ADP-ribose), polymerase, and NAD(P) glycohydrolase $(43,44)$, which hydrolyze only the oxidized molecule (NAD or NADP). It has been proposed that oxidant exposure can produce a breakdown of mi- tochondrial pyridine nucleotide to ADP-ribose and nicotinamide, which can pass through membranes $(45,46)$. This may explain the loss of nicotinamide in the present study, and reflect the fall in NAD levels. While no increase of free acid soluble ADP-ribose was detected under our experimental conditions, ADP-ribose is usually found bound to proteins and can alter their functions (46-48). Nuclear poly(ADP-ribose) polymerase activity has been shown to increase under various conditions that cause DNA damage (49-51), and is associated with NAD depletion in irradiated cells $(50,52)$ and in cells exposed to alkylating agents $(53,54)$ or adenosine deaminase inhibitors $(51)$. In work to be reported separately, we have observed that exposure of cells to $\mathrm{H}_{2} \mathrm{O}_{2}$ induces rapid DNA-strand-breaks, increases poly-(ADP-ribose) polymerase activity, and that inhibition of this enzyme considerably reduces $\mathrm{H}_{2} \mathrm{O}_{2}$-induced depletion of NAD and ATP.

While various oxidants $\left(\mathrm{O}_{2}^{-}, \mathrm{H}_{2} \mathrm{O}_{2}, \mathrm{HOCl}\right.$, and $\left.\mathrm{OH}\right)$ may be produced by activated neutrophils or macrophages, $\mathrm{H}_{2} \mathrm{O}_{2}$ itself seems to be the agent responsible for initiating death in target cells, either directly $(1,55)$ or by initiation of lipid radical formation (56). Changes occurring in the $\mathrm{H}_{2} \mathrm{O}_{2}$ intracellularly are highly controversial. Even with the high doses of $\mathrm{H}_{2} \mathrm{O}_{2}$ (1-5 $\mathrm{mM}$ ) used in this study P388D1 cells were extremely resistant to glutathione oxidation which was presumably due to their high HMPS activity. Glutathione oxidation can occur, however, even in vivo in the proximity of stimulated neutrophils. Glutathione is lost from whole lung tissue of rabbits during the generation of oxidants, including $\mathrm{H}_{2} \mathrm{O}_{2}$, in the development of inflammatory injury (8). In similar studies, GSSG was also released into the plasma (57). The fall in NAD in P388D1 cells was observed with concentrations of $\mathrm{H}_{2} \mathrm{O}_{2}(50 \mu \mathrm{M}$ and higher) that can be easily achieved in the proximity of stimulated neutrophils. As additional evidence that the range of $\mathrm{H}_{2} \mathrm{O}_{2}$ concentrations employed in the present study is attainable when leukocytes are stimulated, P388D1 cells were found to lose ATP when exposed to phorbol myristate acetate-stimulated polymorphonuclear leukocytes (25). The loss of ATP was linked to both stimulation of the HMPS and depletion of NAD.

\section{Acknowledgments}

This work was supported in part by U. S. Public Health Service grants AI17354 and HL16411.

\section{References}

1. Nathan, C. F., S. C. Silverstein, L. H. Brukner, and Z. A. Cohn. 1979. Extracellular cytolysis by activated macrophages and granulocytes. II. Hydrogen peroxide as a mediator of cytotoxicity. J. Exp. Med. 149: 100-113.

2. Simon, R. H., C. H. Scoggin, and D. Patterson. 1981. Hydrogen peroxide causes the fatal injury to human fibroblasts exposed to oxygen radicals. J. Biol. Chem. 256:7181-7186.

3. Weiss, S. J., J. Young, A. F. LoBuglio, and A. Slivka. 1981. Role of hydrogen peroxide in neutrophil-mediated destruction of cultured endothelial cells. J. Clin. Invest. 68:714-724.

4. Arrick, B. A., C. F. Nathan, O. W. Griffith, and Z. A. Cohn. 1982. Glutathione depletion sensitizes tumor cells to oxidative cytolysis. $J$. Biol. Chem. 257(3):1231-1237.

5. Harlan, J. M., J. D. Levine, K. S. Callahan, B. R. Schwartz, and L. A. Harker. 1984. Glutathione redox cycle protects cultured endothelial cells against lysis by extracellularly generated hydrogen peroxide. J. Clin. Invest. 73:706-713. 
6. Sies, H., C. Gerstenecker, H. Menzel, and L. Flohe. 1972. Oxidation in the NADP-system and release of GSSG from hemoglobin-free perfused rat liver during peroxidative oxidation of glutathione by hydroperoxidase. FEBS (Fed. Eur. Biochem. Soc.) Lett. 27:171-175.

7. Oshino, N., and B. Chance. 1977. Properties of glutathione release during reduction of organic hydroperoxide, demethylation of aminopyrine and oxidation of some substances in perfused rat liver and their implications for the physiological function of catalase. Biochem. J. 162: 509-525.

8. Schraufstätter, I. U., S. D. Revak, and C. G. Cochrane. 1984. Proteases and oxidants in experimental pulmonary inflammatory injury. J. Clin. Invest. 73:1175-1184.

9. Kondo, T., G. L. Dale, and E. Beutler. 1980. Glutathione transport by inside-out vesicles from human erythrocytes. Proc. Natl. Acad. Sci. USA. 77:6359-6362.

10. Erklow, L., P. Moldeus, and S. Orrenius. 1984. Oxidation of glutathione during hydroperoxide metabolism: a study using isolated hepatocytes and the glutathione inhibitor 1,3 bis( 2 chloroethyl)-1-nitrosourea. Eur. J. Biochem. 138:459-463.

11. Brigelius R., C. Muckel, T. P. M. Akerboom, and H. Sies. 1983. Identification and quantification of glutathione in hepatic protein-mixed disulfides and its relationship to glutathione disulfide. Biochem. Pharmacol. 32:2529-2534.

12. Orrenius, S., S. A. Jewell, G. Bellomo, H. Thor, D. P. Jones, and M. T. Smith. 1983. Regulation of calcium regulation in the hepatocytea critical role of glutathione. In Functions of Glutathione: Biochemical, Physiological, Toxicological and Clinicaloaspects. A. Larsson, S. Orrenius, A. Holmgren, and B. Mannervik, editors. Raven Press, NY, 261-273.

13. Brigelius, R. 1983. Glutathione oxidation and oxidation of pentose phosphate cycle during hydroperoxide metabolism. Hoppe-Seyler's $Z$. Physiol. Chem. 364:989-996.

14. May, J. M. 1981. The role of glutathione on rat adipocyte pentose phosphate cycle activity. Arch. Biochem. Biophys. 207:117-127.

15. Eaton, J. W., and G. L. Brewer. 1975. The pentose phosphate shunt. In The Red Blood Cell, Vol. I. Surgenor, editor. Academic Press, Inc., NY, 435-471.

16. Griffith, O. W., and A. Meister. 1979. Potent and specific inhibition of glutathione synthesis by butathione sulfoximine (S-n-butylhomocysteine sulfoximine). J. Biol. Chem. 254:7558-7560.

17. Griffith, O. W. 1980. Determination of glutathione and glutathione disulfide using glutathione reductase and 2-vinyl-pyridine. Anal. Biochem. 106:207-212.

18. Brehe, J. E., and H. B. Burch. 1976. Enzymatic assay for glutathione. Anal. Biochem. 74:189-197.

19. Reed, D. J., J. R. Babson, P. W. Beatty, A. E. Brodie, W. W. Ellis, and D. W. Potter. 1980. High-performance liquid chromatography analysis of nanomole levels of glutathione, glutathione disulfide, and disulfides, Anal. Biochem. 106:55-62.

20. Meredith, M. J. 1983. Analysis of protein-glutathione mixed disulfides by performance liquid chromatography. Anal. Biochem. 131: 504-509.

21. Jorgensen, B. M., and H. N. Rasmussen. 1979. Recycling analysis of nicotinamide-adenine dinucleotide phosphates (NADP and NADPH). Anal. Biochem. 99:297-303.

22. Karp, M. T., R. P. Raunio, and T. N. E. Lovgren. 1983. Simultaneous extraction and combined bioluminescent assay of $\mathrm{NAD}^{+}$and NADH. Anal. Biochem. 128:175-180.

23. Heard, J. T. 1983. Thin-layer chromatographic separation of intermediates of the pyridine nucleotide cycle. Anal. Biochem. 130:185188.

24. Pogolotti, A. L., and D. V. Santi. 1982. High-performance liquid chromatography-ultraviolet analysis of intracellular nucleotides. Anal. Biochem. 126:335-345.

25. Spragg, R. G., D. B. Hinshaw, P. A. Hyslop, I. U. Schraufstätter, and C. G. Cochrane. 1984. Alterations in ATP and energy charge in cultured endothelial and P388D1 cells following oxidant injury. J. Clin. Invest. In press.

26. Hyslop, P. A., and L. A. Sklar. 1984. A quantitative fluorimetric assay for the determination of oxidant production of polymorphonuclear leukocytes: its use in the simultaneous fluorimetric assay of cellular activation processes. Anal. Biochem. 141:280-286.

27. De Loecker, P. 1961. Factors influencing the hexose monophosphate shunt in red cells. Clin. Chim. Acta. 6:641-47.

28. Frischer, H., and T. Ahmad. 1977. Severe generalized glutathione reductase deficiency after anti-tumor therapy with BCNU [1,3bis(chloroethyl)-1-nitrosourea]. J. Lab. Clin. Med. 89:1080-1091.

29. Orrenius, S., K. Ormstad, H. Thor, and S. A. Jewell. 1983. Turnover and functions of glutathione, studied with isolated hepatic and renal cells. Fed. Proc. 42:3177-3188.

30. Ishikawa, T., and H. Sies. 1984. Cardiac transport of glutathione disulfide and S-conjugate studies with isolated perfused rat heart during hydroperoxide metabolism. J. Biol. Chem. 259(6):3838-3843.

31. Trotta, R. J., S. G. Sullivan, and A. Stern. 1982. Lipid peroxidation and haemoglobin degradation in red blood cells exposed to t-butyl-hydroperoxide. Biochem. J. 204:405-415.

32. Haest, C. W. M., D. Kamp and B. Deuticke. 1977. Intra- and intermolecular cross-linking of membrane proteins in intact erythrocytes and ghosts by SH-oxidizing agents. Biochim. Biophys. Acta. 557:363371.

33. Allen, D. W., G. J. Johnson, S. Cadman, and M. E. Kaplan. 1978. Membrane polypeptide aggregates in glucose-6-phosphate dehydrogenase deficient and in vitro aged red blood cells. J. Lab. Clin. Med. 91:321-330.

34. Haest, C. W. M., D. Kamp, and B. Deuticke. 1979. Formation of disulfide bonds between glutathione and membrane SH-groups in human erythrocytes. Biochim. Biophys. Acta. 557:363-368.

35. Offermann, M. K., M. J. McKay, M. W. Marsh, and J. S. Bond. 1984. Glutathione disulfide inactivates, destabilizes, and enhances proteolytic susceptibility of fructose-1,6-biphosphate aldolase. J. Biol. Chem. 259:8886-8891.

36. Eggleston, L. V., and H. A. Krebs. 1974. Regulation of the pentose phosphate shunt. Biochem. J. 138:425-435.

37. Crane, D., D. Haussinger, P. Graf, and H. Sies. 1983. Decreased flux through pyruvate dehydrogenase by thiol oxidation during t-butylhydroperoxide metabolism in perfused rat liver. Hoppe Seyler's Z. Physiol. Chem. 364:989-996.

38. Baba, A., E. Lee, T. Matsuda, T. Kihara, and H. Iwata. 1978. Reversible inhibition of adenylate cyclase activity of rat brain caudate nucleus by oxidized glutathione. Biochem. Biophys. Res. Commun. 85(3): 1204-1210.

39. Gilbert, H. J. 1982. Biological disulfides: the third messenger modulation of phosphofructokinase activity by thiol/disulfide exchange. J. Biol. Chem. 257:12086-12091.

40. Weitzman, S. A., and T. P. Stossel. 1982. Effects of oxygen radical scavengers and antioxidants on phagocyte-induced mutagenesis. J. Immunol. 128:2770-2772.

41. Bradley, M. O., and L. C. Erickson. 1980. Comparison of the effects of hydrogen peroxide and $\mathrm{x}$-ray irradiation on toxicity, mutation, and DNA damage/repair in mammalian cells (V-79). Biochim. Biophys. Acta. 654:135-141.

42. Lesko, S. A., J. L. Drocourt, and S. U. Yang. 1982. Deoxyribonucleic acid-protein and deoxyribonucleic acid interstrand cross-links induced in isolated chromatin by hydrogen peroxide and ferrous ethylenediaminetetraacetate chelates. Biochemistry. 21(20):5010-5015.

43. McCreanor, G. M., and D. A. Bender. 1983. The role of catabolism in controlling tissue concentration of nicotinamide nucleotide coenzymes. Biochim. Biophys. Acta. 759-222-228.

44. Cayama, E., R. Apitz-Castro, and E. Cordes. 1973. Substratedependent, thiol-dependent, inactivation of brain nicotinamide adenine dinucleotide glycohydrolase. J. Biol. Chem. 18:6479-6483.

45. Lotscher, H. R., K. H. Winterhalter, E. Carfori, and C. Richter. 1980. Hydroperoxide induced loss of pyridine nucleotides and release of $\mathrm{Ca}^{++}$from rat liver mitochondria. J. Biol. Chem. 255:9325-9330.

46. Richter, C., K. H. Winterhalter, S. Baumhuter, H. R. Lotscher, and B. Moser. 1983. ADP-ribosylation in inner membrane of rat liver mitochondria. Proc. Natl. Acad. Sci. USA. 80:3188-3192. 
47. Bokoch, G. M., T. Katada, J. K. Northup, E. L. Hewlett, and A. G. Gilman. 1983. Identification of the predominant substrate for ADP-ribosylation by islet activating protein. J. Biol. Chem. 258:20722075.

48. Ajmer, F., B. Scharrer, F. Hashimoto, and P. E. Carson. 1967. Interrelation of stromal NAD(P)ase and human erythrocyte 6-phosphogluconic dehydrogenase. Proc. Nat. Acad. Sci. USA. 59:538-541.

49. Durkacz, B. W., O. Onudiji, D. A. Gray, and S. Shall. 1980. (ADP-ribose)n participates in DNA excision repair. Nature (Lond). 283: 593-596.

50. Skidmore, C. J., M. I. Davies, P. M. Goodwin, H. Halldorsson, P. J. Lewis, S. Shall, and A. A. Zia'ee. 1979. The involvement of poly(ADP-ibose) polymerase in the degradation of NAD caused by gamma irradiation and N-methyl-N-nitrosourea. Eur. J. Biochem. 101: $135-142$.

51. Seto, S., C. J. Carrera, M. Dubota, D. B. Wasson, and D. A. Carson. 1985. Mediation of deoxyadenosine and 2-chlorodeoxyadenosine toxicity to nondividing human lymphocytes. J. Clin. Invest. 75:377383.
52. Wielckens, K., A. Schmidt, E. George, R. Bredehorst, and H. Hilz. 1982. DNA fragmentation and NAD depletion: their relation to the turnover of endogenous mono(ADP-ribosyl) and poly(ADP-ribosyl) proteins. J. Biol. Chem. 257(21):12872-12877.

53. Smulson, M. E., P. Schein, D. W. Mullins, and S. Sudhakar. 1977. A putative role for nicotinamide adenine dinucleotide-promoted nuclear protein modification in the antitumor activity of N-methyl-Nnitrosourea. Cancer Res. 37:3006-3012.

54. Yamamoto, H., Y. Uchigata, and H. Okamoto. 1981. Strepozotocin and alloxan induce DNA strand breaks and poly(ADP-ribose) synthetase in pancreatic islets. Nature (Lond.). 294:284-286.

55. Nathan, C. F. 1982. Secretion of oxygen intermediates: role in effector functions of activated macrophages. Fed. Proc. 41:2206-2211.

56. Rubin, R., and J. L. Farber. 1984. Mechanisms of the killing of cultured hepatocytes by hydrogen peroxide. Arch. Biochem. Biophys. 228:450-459.

57. Gurtner, G. H., A. L. Knoblauch, E. Cadenas, and H. Sies. 1985. Correlation between glutathione release and free radical-induced chemiluminescence in the lung. Fed. Am. Soc. Exp. Biol. 44(4):916. (Abstr.) 